\title{
Comparison between polypropylene and polypropylene with poliglecaprone meshes on intraperitoneal adhesion formation
}

\section{Estudo comparativo entre tela de polipropileno e poliglecaprone com tela de polipropileno na formação de aderências intraperitoneais}

Maria de lourdes Pessole Biondo-Simões, tCBC-PR¹; Wagner Augusto Schiel'; Mayara Arantes ${ }^{1}$; Tatiane da Silveira ${ }^{1}$; Rogério Ribeiro Robes ${ }^{1}$; Flávio Daniel SaAvedra Tomasich, TCBC-PR ${ }^{1}$.

\section{A B S T R A C T}

\begin{abstract}
Objective: to compare intraperitoneal adhesion formation in rats when using polypropylene and polypropylene with poliglecaprone meshes. Methods: we used twenty male, Wistar rats, divided in two groups. In group 1, the rats received the polypropylene mesh on their right side and the polypropylene with poliglecaprone mesh on their left side. In group 2 the position of the meshes was inverted. After 30 days, we analyzed the presence or not of adhesion formation, including only those over the meshes. The findings undergone an analysis through the Mann-Whitney test, at a level of significance of $p \leq 0.05$. Results: all meshes presented adhesions. We verified that, for the polypropylene meshes, the percentage of their surface covered by adhesions varied from 10.5 to $100 \%$, with an average of $34.07 \pm 24.21 \%$, while for the polypropylene with poliglecaprone mesh, the percentage covered by adhesions varied between $8.5 \%$ and $100 \%$, with an average of $44.7 \pm 32.85 \%(p=0.12)$. Conclusion: both meshes lead to adhesion formation, none being superior to the other.
\end{abstract}

Keywords: Hernia. Tissue Adhesions. Surgical Mesh. Comparative Study.

\section{INTRODUCTION}

I Incisional hernia or eventration is a protrusion of abdominal contents through a weakened area on the abdominal wall, as a result of trauma or a surgical incision. It is a common complication of abdominal surgeries, occurring in $2 \%$ to $35 \%$ of laparotomies ${ }^{1-3}$ and causing significant morbidity and mortality. A considerable number of patients presents with bowel strangulation (2\%) and incarceration (6-15\%).

The repair of incisional hernias is surgical, with many techniques described. The advent of the use of prosthesis could significantly reduce the recurrence rate when compared with the primary correction ${ }^{4}$. Through laparoscopic approaches, the meshes reached the abdominal cavity. Thus, by being in contact with abdominal structures, they have brought complications such as adhesions, fistulae and intestinal obstructions ${ }^{5,6}$. A systematic review by Castro et al. ${ }^{7}$ reports that $4.7 \%$ of patients that had undergone laparoscopy required enterectomies, a condition capable of raising mortality to $2.8-7.7 \% 8$.
Peritoneal adhesions are present in 90\% of patients undergoing abdominal surgery and can cause complications such as intestinal obstruction, infertility, chronic pelvic and abdominal pain, besides difficulties on reoperation ${ }^{9}$. A study by van Goor ${ }^{10}$ draws attention, also, to longer periods of hospitalization, duration of surgery, and the need for conversion of laparoscopy to laparotomy. The most commonly used surgical mesh is the polypropylene mesh, because of its flexibility, stimulation of cell growth, satisfactory inflammatory response, ease of handling and low cost. However, this prosthesis induces the formation of adhesions when in contact with intra-abdominal contents ${ }^{11}$, justifying the search for meshes that would provoke less complications, while maintaining tissues' resistance and tensile strength ${ }^{12}$.

Within this context, several prostheses have been developed, differing in aspects such as composition material, pore size, weight, elasticity, tissue reaction, absorption and biocompatibility ${ }^{13}$. A review by Araújo et al. ${ }^{14}$ recommends the use of composite meshes for intraperitoneal use. Among these meshes,

1 - Federal University of Paraná, Discipline of Surgical Technique and Experimental Surgery, Curitiba, Paraná State, Brazil. 
figures the Ultrapro®, a partially absorbable prosthesis, composed of equal parts of polypropylene and poliglecaprone, incorporating high tensile strength, with good biocompatibility, despite the light weight ${ }^{15}$.

The objective of this study is to compare the formation of intraperitoneal adhesions between the meshes made of polypropylene and polypropylene associated with poliglecaprone.

\section{METHODS}

The project was submitted to the Ethics Committee for Use in Animals of the Biological Sciences Department at the Federal University of Paraná (UFPR), under registry number 23075.006274/201448, having been approved.

The sample consisted of 20 male Wistar rats, aged between 100 and 120 days old each, and weighting 316 to 400 grams, with an average weight of $360.5 \pm 19.32$ grams. The animals were allocated at the Vivarium of the Discipline of Surgical Technique and Experimental Surgery of UFPR during the experiment, with free access to food and water.

We randomly divided the sample into two groups, with ten rats each. We inserted both meshes in each animal on the ventral wall on the intraperitoneal face, so that each rat would be its own control. In Group 1, the polypropylene mesh was disposed on the peritoneal surface, to the right side of the midline incision, and the polypropylene with poliglecaprone mesh was placed on the left side. In Group 2, we inverted the disposition of the meshes. After 28 days of the procedure, we euthanized the rats.

The animals underwent anesthesia with $0.1 \mathrm{ml} / 100 \mathrm{~g}$ weight of a composite solution of ketamine (50mg) and xylazine (20mg), complemented with inhalatory isoflurane. We performed a midline, $4 \mathrm{~cm}$, xifo-pubic incision. We placed the $10 \times 20 \mathrm{~mm}$ size meshes intraperitoneally, according to the group of the corresponding animal, and fixed them with 5.0 polypropylene. The skin was sutured using 4.0 nylon. Analgesia was done with a $10 \mathrm{mg} / \mathrm{kg}$ intramuscular injection of dipyrone. After 28 days of the procedure, we carried the euthanasia, according to the CONCEA Guidelines for the Practice of Euthanasia, 2013, and the Brazilian Guide for Good Practice in Animal Euthanasia from the Federal Council of Veterinary Medicine, 2013. We performed it with the intravenous administration of a $10 \%$ Potassium Chloride solution, $5 \mathrm{mg} / \mathrm{kg}$, under anesthesia with intravenous Thiopental, $10 \mathrm{mg} / \mathrm{kg}$, and inhalatory isoflurane.

We them opened the abdominal cavity with a U-shaped incision that, when lifted, allowed the evaluation of adhesions. We analyzed their presence or absence, including only adhesions on the meshes and excluding those on the midline suture and on the transfixing stitches, since regardless of the prosthesis used, there is a predisposition of the tissue to form adhesions on suture locations ${ }^{16}$.

For the evaluation, the area affected by the adhesions was projected in graph paper, on a sketch of the same size of the mesh $(10 \times 20 \mathrm{~mm})$. For more precision, visceral adhesions were sectioned and put out to analyze the previously hidden portion of the mesh. From these projections over the graph paper, we obtained the percentage of mesh covered by adhesions. The mesh attached to the peritoneum was considered incorporated, and when held only by the fixation points, was treated as not incorporated.

The results were then submitted to statistical analysis through the Mann Whitney test for evaluation of the mean and the Fisher's test for the frequency, adopting $p \leq 0.05$, or $5 \%$, as the level of significance.

\section{RESULTS}

There were no post-operative complications or deaths. One polypropylene mesh and seven polypropylene with poliglecaprone meshes did not show incorporation to the parietal peritoneum (Table 1). In addition, all the meshes presented with adhesions.

In Group I, the percentage of the meshes' surface covered by adhesions on the right side (polypropylene) varied from $12 \%$ to $49 \%$, with a mean of $25.69 \pm 13.61 \%$, while on the left side (polypropylene with poliglecaprone), the covered surface percentage 
Table 1. Number of incorporated meshes.

\begin{tabular}{cccc}
\hline Incorporation & Polypropylene & Polypropylene with Polyglecaprone & Total \\
\hline Yes & 19 & 13 & 32 \\
No & 1 & 7 & 8 \\
\hline Total & 20 & 20 & 40 \\
\hline
\end{tabular}

Fisher's exact test à 0.0201

ranged from $13 \%$ to $100 \%$, with an average of $49.45 \% \pm 25.57(p<0.05)$ (Table 2, Figure 1).

In Group II, the percentage of the meshes' surface covered by adhesions on the right side (polypropylene with poliglecaprone) varied from $8.5 \%$ to $100 \%$, with an average of $39.95 \pm 36.77 \%$, while on the left side (polypropylene), the percentage ranged from $15 \%$ to $100 \%$, with a mean of $42.45 \pm 28.07 \%$ ( $p>0.05$ ) (Table 3, Figure 2).

Regardless of the groups, we found that the polypropylene mesh had the percentage of the surface covered by adhesions ranging from $10.5 \%$ to $100 \%$, with a mean value of $34.07 \pm 24.21 \%$, while on the polypropylene with poliglecaprone mesh, the covered percentage varied from $9 \%$ to $100 \%$, with an average of $44.7 \pm 32.85 \%(p=0.12)$ (Table 4, Figure 3$)$. In both meshes, adhesions were to the omentum (98.5\%) and

Table 2. Percentage of mesh surface covered by adhesions in Group 1.

\begin{tabular}{ccc}
\hline & \multicolumn{2}{c}{ Area with adherences } \\
Animal & Right Side & Left Side \\
\hline 1 & 18.5 & 100 \\
2 & 37.5 & 53.5 \\
3 & 49 & 80 \\
4 & 17.4 & 44 \\
5 & 10.5 & 68.5 \\
6 & 25 & 13 \\
7 & 12 & 43 \\
8 & 19 & 30 \\
9 & 49 & 42 \\
10 & 19 & 20.5 \\
\hline Mean & 25.69 & 49.45 \\
SD* & 13.62 & 25.57 \\
\%SD* & 53.02 & 51.71 \\
\hline
\end{tabular}

* $S D=$ Standard derivation Mann-Whitney's test $p<0.05$ the spermatic cord (80\%). The liver was present in $20 \%$ of cases ( $5 \%$ in the polypropylene and $15 \%$ of the polypropylene with poliglecaprone) and the small bowel in $2.5 \%$ of cases (Figure 4).

\section{DISCUSSION}

The intraperitoneal use of surgical meshes in the repair of incisional hernias can induce the formation of adhesions, intestinal obstruction and fistulae $e^{5,6}$. The direct contact of the prosthesis with the viscera contributes significantly to the process ${ }^{11}$. In a study by Halm et al. ${ }^{17}, 76 \%$ of patients in which the mesh was placed intraperitoneally developed adhesions, of whom $20 \%$ needed bowel resection. In addition, complications were present in $77 \%$ of patients who required reoperation, increasing the incidence of postoperative complications. The most feared complication, intestinal obstruction, is associated with higher rates of morbidity and mortality ${ }^{9,10}$, what drives the search for a composition of meshes that present fewer complications, while maintaining resistance and strength to traction.

When inserted intraperitoneally, in general a mesh induces a foreign body reaction and the

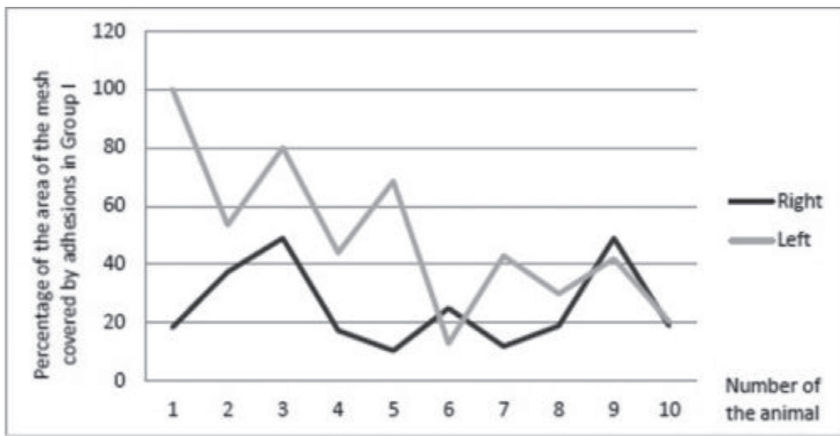

Figure 1. Percentage of mesh area covered by adhesions in group I. Note: right Side - polypropylene; left side - polypropylene with poliglecaprone. 
Table 3. Percentage of mesh surface covered by adhesions in Group 2.

\begin{tabular}{ccc}
\hline & \multicolumn{2}{c}{ Area with adherences } \\
Animal & Right Side & Left Side \\
\hline 11 & 100 & 20 \\
12 & 44 & 56.5 \\
13 & 8.5 & 18 \\
14 & 10 & 17 \\
15 & 9 & 76 \\
16 & 80 & 62.5 \\
17 & 10 & 26.5 \\
18 & 100 & 100 \\
19 & 13 & 33 \\
20 & 25 & 15 \\
\hline Mean & 39.95 & 42.45 \\
SD* & 36.77 & 28.08 \\
\%SD* & 92.04 & 66.15 \\
\hline
\end{tabular}

* $S D=$ Standard derivation Mann-Whitney's test $p<0.05$

formation of adhesions, which represent a pathological process of the peritoneal healing ${ }^{18}$. Among the main causes of adhesions are the presence of foreign bodies, peritoneal inflammation, ischemia, trauma and abrasion ${ }^{19}$. Surgical trauma triggers an inflammatory process that comprises both vascular and cellular changes, as well as the formation of a fibrin matrix, which gradually results in the development of a tissue composed of fibroblasts, macrophages, and other inflammatory cells. This process of peritoneal repair is involved with the incorporation of the prosthesis, and may progress to the formation of adhesions ${ }^{20}$.

With the advent of the laparoscopic approach and the consequent increase in the incidence of adhesions $^{5,6,10}$, the demand for meshes with lower complications has gained strength. An ideal mesh it should: not induce the formation of adhesions; not trigger allergic or foreign body reactions; not be carcinogenic, adhesive or erosive; resist infection; be adjustable to the abdominal wall; and have good resistance and tensile strength ${ }^{11}$. However, for Minossi et al., no material would present all of them ${ }^{21}$. The material, its weight and porosity exert influence on the formation of adhesions, on the intensity of inflammatory reaction and on

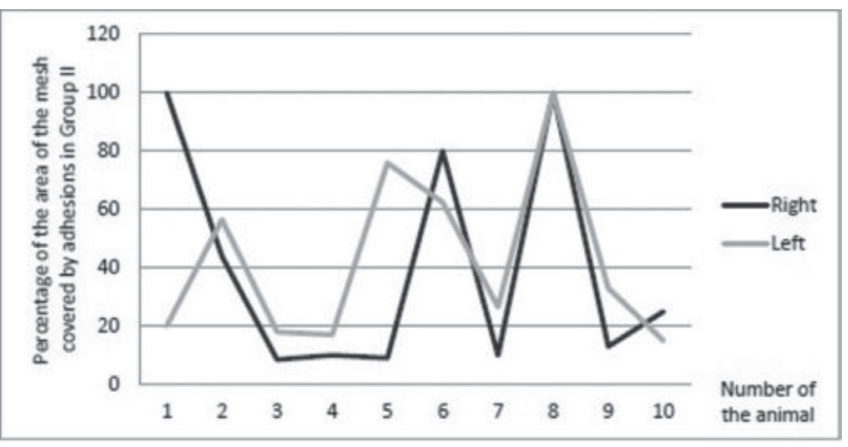

Figure 2. Percentage of mesh area covered by adhesions in Group II. Note: right side - polypropylene with poliglecaprone; left side-polypropylene.

the consistency and tissue organization of the peritoneum in recovery 22 .

Experimental studies with surgical meshes for evaluation of biocompatibility and adhesion formation use animal models, such as rabbits ${ }^{23-25}$, sheep ${ }^{26}$, pigs $^{15}$, and, especially, rats ${ }^{11,27}$. The variables analyzed include incidence, extent, quality and, in some studies, resistance to rupture and tenacity.

The polypropylene mesh with heavy weight $\left(80-100 \mathrm{~g} / \mathrm{m}^{2}\right)$ and average pore size $(0.8 \mathrm{~mm})$ is currently the most used ${ }^{5}$. Consecrated by its excellent biocompatibility, incorporation, maintenance of abdominal wall traction and low cost, it is associated with a high incidence of adhesions $^{14,22}$. In experimental studies, the formation of adhesions is observed in $100 \%$ of meshes, covering from $50 \%$ to $100 \%$ of their surface $e^{11,12,27}$. The authors described the omentum as the most often involved structure, followed by the liver and the bowel.

In this study, we observed adhesions in 100\% of animals in which we implanted the polypropylene mesh. The percentage of mesh covered by adhesions varied from $10.5 \%$ to $100 \%$, with an average of $34.07 \pm 24.21 \%$. We could observe a higher formation of adhesions on the left side, where the percentage of mesh covered ranged from $15 \%$ to $100 \%$, with a mean of $42.45 \pm 28.07 \%$, versus $12-49 \%$ of surface covered and average of $25.69 \pm 13.61 \%$ on the right side. Moreover, only one of the 20 implanted meshes did not show incorporation to the parietal peritoneum.

Adhesions involving the small intestine represent greater risk for development of bowel obstruction ${ }^{19}$. However, in some cases the omentum 
Table 4. Percentage of area covered by adhesions in both meshes, regardless of insertion side.

\begin{tabular}{|c|c|c|}
\hline \multirow[b]{2}{*}{ Animal } & \multicolumn{2}{|c|}{ Area with adherences } \\
\hline & Polypropylene & $\begin{array}{c}\text { Polypropylene with } \\
\text { Polyglecaprone }\end{array}$ \\
\hline 1 & 18.5 & 100 \\
\hline 2 & 37.5 & 53.5 \\
\hline 3 & 49 & 80 \\
\hline 4 & 17.4 & 44 \\
\hline 5 & 10.5 & 68.5 \\
\hline 6 & 25 & 13 \\
\hline 7 & 12 & 43 \\
\hline 8 & 19 & 30 \\
\hline 9 & 49 & 42 \\
\hline 10 & 19 & 20.5 \\
\hline 11 & 20 & 100 \\
\hline 12 & 56.5 & 44 \\
\hline 13 & 18 & 8.5 \\
\hline 14 & 17 & 10 \\
\hline 15 & 76 & 9 \\
\hline 16 & 62.5 & 80 \\
\hline 17 & 26.5 & 10 \\
\hline 18 & 100 & 100 \\
\hline 19 & 33 & 13 \\
\hline 20 & 15 & 25 \\
\hline Mean & 34.07 & 44.7 \\
\hline$S D^{*}$ & 24.21 & 32.85 \\
\hline$\% S D *$ & 71.09 & 73.51 \\
\hline
\end{tabular}

* SD= Standard derivation Mann-Whitney's test $p<0.05$

might as well be involved. In addition, the heavy weight polypropylene meshes, weighting more than 40mg/ $\mathrm{m}^{2}$, are related to complications such as abdominal discomfort, infection and fistulae. In turn, the porosity of the material influences cell colonization and inflammatory reaction. Meshes with small pores induce a subtle cell colonization, but intense inflammatory reaction and adhesion formation. In contrast, large pore meshes, in addition to being more flexible, ensure lower foreign body reaction, allowing their integration to the tissues without the formation of a fibrous capsule ${ }^{14,22}$.

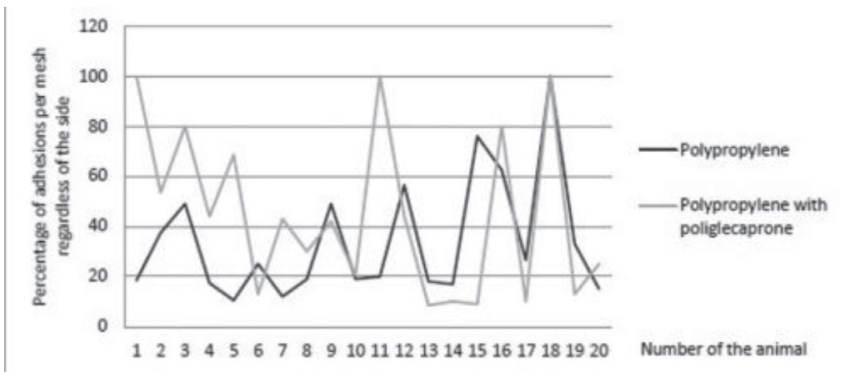

Figure 3. Percentage of adhesions per mesh regardless of insertion side.

In this context, the association of polypropylene mesh with poliglecaprone filaments would allow fewer complications compared with the classic polypropylene mesh. The absorbable component of the prosthesis, poliglecaprone, would facilitate the intraoperative handling of the mesh, on both endoscopic and open repair ${ }^{15}$. The mesh used in thisstudy consisted of equal parts of low weight $\left(28 \mathrm{~g} / \mathrm{m}^{2}\right)$ polypropylene with large pores (3-4mm) and poliglecaprone, characterized by its good biocompatibility, both histological and immunochemical, in addition to its extensive development and high tensile strength ${ }^{11,15}$.

In an experimental model using Wistar rats, Burger et al. ${ }^{11}$ compared the polypropylene and poliglecaprone mesh to other prostheses, evaluating adhesion formation, incorporation and tensile strength. The analysis was carried out seven and 30 days after the insertion procedure. The polypropylene with poliglecaprone mesh was not superior to the polypropylene one.

Schreinemacher et al. ${ }^{16}$ also did not found significant differences between the polypropylene and the polypropylene with poliglecaprone meshes when they studied adhesion formation and incorporation after seven and 30 days postoperatively in rats in a study with six prostheses. The authors reported a smaller area covered by adhesions in the group evaluated at 30 days, but this difference was not significant. In that group, also, all the animals that received the polypropylene with poliglecaprone mesh developed visceral adhesions, versus 35\% in those with polypropylene mesh. As of incorporation, there were no significant differences between the meshes. 


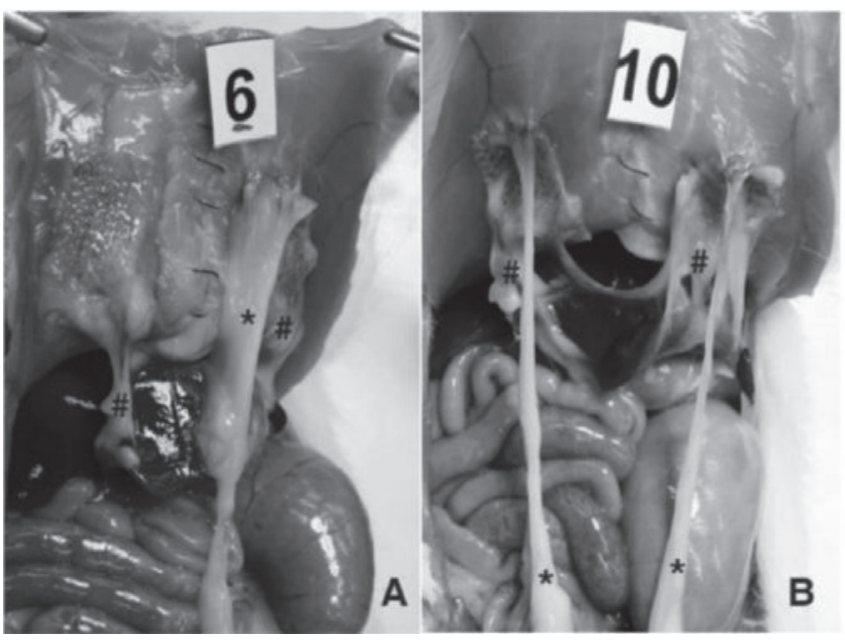

Figure 4. Adhesions in animals 6 and 10 from Group I (polypropylene mesh on the right and polypropylene with poliglecaprone mesh on the left). Note: ${ }^{*}=$ spermatic cord; \# = omentum.

Bellón et al. ${ }^{25}$ analyzed the polypropylene with poliglecaprone mesh and other prostheses in the correction of defects of the abdominal wall in rabbits. With respect to adhesions, there was no significant difference when compared to the polypropylene mesh. Still, the adhesions were observed through laparoscopy after 72 hours of the procedure, showing no difference when analyzed seven and 14 days postoperatively.

Aramayo et al. ${ }^{23}$ produced an incisional hernia in 40 rabbits and evaluated three prostheses used for repair. The area of adhesion induced by the polypropylene mesh was significantly larger when compared with the mesh made of polypropylene with poliglecaprone.

Bellón et $a / .^{24}$, in an experimental model using rabbits, compared the lightweight polypropylene mesh with the polypropylene with poliglecaprone one. After analysis at 14 and 90 days after the procedure, they concluded that the formation of adhesions in the peritoneal face of the prosthesis was significantly less extensive on the mesh with absorbable component at 90 days. The adhered structures were the omentum and the bowel.

The results of the current work agree with those presented by different studies regarding adhesion formation. All meshes induced the formation of adhesions and there was no significant difference between them. For the mesh made of polypropylene with poliglecaprone, the percentage covered by adhesions ranged between 8.5 and $100 \%$, averaging $44.7 \pm 32.85 \%(p=0.12)$. After evaluating each animal within a group, we noticed a significant difference on adhesion formation between them, which hinders the establishment of a pattern. This variation may be related to the individual response of each of the animals. This prosthesis also presented a higher incidence of adhesions involving the liver, 15\% versus $5 \%$ with the polypropylene mesh.

When inserted on the left side, the percentage of mesh covered by adhesions was significantly higher when compared with the polypropylene mesh. However, when analyzed regardless of the insertion site, none of the meshes proved to be significantly superior to the other. The different intra-abdominal organ disposition between the sides and the increased mobility of the omentum, which was present in $98.5 \%$ of the sample adhesions, may justify this disparity. In turn, as of incorporation, the difference was significant. Out of 20 implemented meshes, seven did not show incorporation, as opposed to only one of the polypropylene meshes.

Among the modifications applied to prostheses used in laparotomy closure, the addition of absorbable material to the mesh composition aims to reduce the induction of foreign body reaction, while enhancing the complacency of the abdominal wall ${ }^{28}$. In theory, these changes would ensure lower adhesion formation. However, according to the exposed, the composite mesh was not superior to the standard one. For some authors, also, the foreign body reaction induced by the partially absorbable meshes was higher in the early stages after the procedure, and normalized in a later analysis by Bellón et al. ${ }^{24}$.

It is important to observe that it is difficult to extrapolate the results of experimental studies to the practice in humans, considering that these models use mostly rodents. The biological response of the animals used in experiments can be different from that presented by humans. Furthermore, the different analysis periods used by different studies, 
as well as their different methodologies, contribute to limit the application of experimental studies in medical practice.

Despite increasing research, there are no available meshes that do not induce adhesion formation, and their use remains a challenge, especially when left in contact with abdominal viscera.

The analysis of the results shows that, in rats, both studied meshes have the same ability to form adhesions.

\title{
R E S U M O
}

\begin{abstract}
Objetivo: comparar a formação de aderências intraperitoneais em ratos, com o uso de tela de polipropileno e tela composta de polipropileno e poliglecaprone. Métodos: vinte ratos Wistar machos, foram alocados em dois grupos. No grupo 1 os ratos receberam tela de polipropileno no lado direito e tela de polipropileno e poliglecaprone no lado esquerdo. No grupo 2 inverteu-se a posição das telas. Analisou-se a presença ou não de aderências após 30 dias, sendo incluídas apenas aderências sobre as telas. Os resultados foram submetidos à análise estatística, adotando-se como nível de significância $p \leq 0,05$. Resultados: todas as telas se apresentaram com aderências. Verificou-se que, na tela de polipropileno, a porcentagem de superfície coberta por aderências variou entre 10,5 a 100\%, com média $34,07 \pm 24,21 \%$ enquanto que na tela de polipropileno e poliglecaprone a porcentagem de tela coberta por aderências variou entre 8,5 a $100 \%$, com média $44,7 \pm 32,85 \%(p=0,12)$. Conclusão: ambas as telas dão origem às aderências, não havendo vantagem de aplicação no reparo intraperitoneal de uma em relação à outra.
\end{abstract}

Descritores: Hérnia. Aderências Teciduais. Telas Cirúrgicas. Estudo Comparativo.

\section{REFERENCES}

1. Fikatas $P$, Schoening $W$, Lee JE, Chopra SS, Seehofer D, Guckelberger $O$, et al. Incidence, risk factors and management of incisional hernia in a high volume liver transplant center. Ann Transplant. 2013;18:223-30.

2. Nakayama M, Yoshimatsu K, Yokomizo H, Yano Y, Okayama S, Satake M, et al. Incidence and risk factors for incisional hernia after open surgery for colorectal cancer. Hepatogastroenterology. 2014;61(133):1220-3.

3. Höer J, Lawong G, Klinge U, Schumpelick V. [Factors influencing the development of incisional hernia. A retrospective study of 2,983 laparotomy patients over a period of 10 years]. Chir. 2002;73(5):47480. German.

4. Luijendijk RW, Hop WC, van den Tol MP, de Lange DC, Braaksma MM, ljzermans JN, et al. A comparison of suture repair with mesh repair for incisional hernia. N Engl J Med. 2000;343(6):392-8.

5. Brown CN, Finch JG. Which mesh for hernia repair? Ann R Coll Surg Engl. 2010;92(4):272-8.

6. Cevasco M, Itani KM. Ventral hernia repair with synthetic, composite, and biologic mesh: characteristics, indications, and infection profile. Surg Infect (Larchmt). 2012;13(4):209-15.
7. Castro PM, Rabelato JT, Monteiro GG, del Guerra GC, Mazzurana M, Alvarez GA. Laparoscopy versus laparotomy in the repair of ventral hernias: systematic review and meta-analysis. Arq Gastroenterol. 2014;51(3):205-11.

8. LeBlanc KA, Elieson MJ, Corder JM 3rd. Enterotomy and mortality rates of laparoscopic incisional and ventral hernia repair: a review of the literature. JSLS. 2007;11(4):408-14.

9. Liakakos T, Thomakos N, Fine PM, Dervenis C, Young RL. Peritoneal adhesions: etiology, pathophysiology, and clinical significance. Recent advances in prevention and management. Dig Surg. 2001;18(4):260-73.

10. van Goor H. Consequences and complications of peritoneal adhesions. Colorectal Dis. 2007;9 Suppl 2:25-34.

11. Burger JW, Halm JA, Wijsmuller AR, ten Raa S, Jeekel J. Evaluation of new prosthetic meshes for ventral hernia repair. Surg Endosc. 2006;20(8):1320-5. Epub 2006 Jul 24.

12. Lamber B, Grossi JVM, Manna BB, Montes JHM, Bigolin AV, Cavazzola LT. Pode a tela de poliéster coberta com colágeno diminuir as taxas aderências intraperitoneais na correção de hérnia incisional? ABCD, arq bras cir dig. 2013;26(1):13-7.

13. Seiler $C$, Baumann $P$, Kienle $P$, Kuthe $A$, Kuhlgatz J, Engemann $\mathrm{R}$, et al. A randomised, multi-centre, 
prospective, double blind pilot-study to evaluate safety and efficacy of the non-absorbable Optilene Mesh Elastic versus the partly absorbable Ultrapro Mesh for incisional hernia repair. BMC Surg. 2010;10(21):1-7.

14. Araújo $U$, Czeczko N. The choice of the mesh composition to use in the intraperitoneal position in the surgical repair of abdominal wall defects. ABCD Arq Bras Cir Dig. 2010;23(2):118-21.

15. Schug-Pass $C$, Tamme C, Sommerer F, Tannapfel A, Lippert H, Köckerling F. A lightweight, partially absorbable mesh (Ultrapro) for endoscopic hernia repair: experimental biocompatibility results obtained with a porcine model. Surg Endosc. 2008;22(4):1100-6.

16. Schreinemacher $\mathrm{MH}$, Emans PJ, Gijbels MJ, Greve JW, Beets GL, Bouvy ND. Degradation of mesh coatings and intraperitoneal adhesion formation in an experimental model. Br J Surg. 2009;96(3):305-13

17. Halm JA, de Wall LL, Steyerberg EW, Jeekel J, Lange JF. Intraperitoneal polypropylene mesh hernia repair complicates subsequent abdominal surgery. World J Surg. 2007;31(2):423-9.

18. Borrazzo EC, Belmont MF, Boffa D, Fowler DL. Effect of prosthetic material on adhesion formation after laparoscopic ventral hernia repair in a porcine model. Hernia. 2004;8(2):108-12. Epub 2003 Nov 21.

19. Cheong YC, Laird SM, Li TC, Shelton JB, Ledger $\mathrm{WL}$, Cooke ID. Peritoneal healing and adhesion formation/reformation. Hum Reprod Update. 2001;7(6):556-66.

20. Kamel RM. Prevention of postoperative peritoneal adhesions. Eur J Obstet Gynecol Reprod Biol. 2010;150(2):111-8.

21. Minossi JG, Silva AL, Spadella CT. O uso da prótese na correção das hérnias da parede abdominal é um avanço, mas o seu uso indiscriminado, um abuso. Rev Col Bras Cir. 2008;35(6):416-24.

22. Klosterhalfen $B$, Junge $K$, Klinge $U$. The lightweight and large porous mesh concept for hernia repair. Expert Rev Med Devices. 2005;2(1):10317.

23. Aramayo AL, Lopes Filho GJ, Barbosa CA, Amaral VF, Costa LA. Abdominal wall healing in incisional hernia using different biomaterials in rabbits. Acta Cir Bras. 2013;28(4):307-16.

24. Bellon JM, Rodriguez M, Garcia-Honduvilla N, Gomez-Gil V, Pascual G, Bujan J. Postimplant behavior of lightweight polypropylene meshes in an experimental model of abdominal hernia. J Invest Surg. 2008;21(5):280-7.

25. Bellón JM, Rodríguez M, García-Honduvilla N, Pascual G, Gómez Gil V, Buján J. Peritoneal effects of prosthetic meshes used to repair abdominal wall defects: monitoring adhesions by sequential laparoscopy. J Laparoendosc Adv Surg Tech A. 2007;17(2):160-6.

26. Zinther NB, Wara P, Friis-Andersen H. Shrinkage of intraperitoneal onlay mesh in sheep: coated polyester mesh versus covered polypropylene mesh. Hernia. 2010;14(6):611-5.

27. Kist C, Manna BB, Montes JHM, Bigolin AV, Grossi JVM, Cavazzola LT. Estudo comparativo de aderências intraperitoneais associadas ao uso das telas de polipropileno e de malha leve de polipropileno revestida com ácido graxo ômega-3. Rev Col Bras Cir. 2012;39(3):201-6.

28. Cobb WS, Burns JM, Peindl RD, Carbonell AM, Matthews BD, Kercher KW, et al. Textile analysis of heavy weight, mid-weight, and light weight polypropylene mesh in a porcine ventral hernia model. J Surg Res. 2006;136(1):1-7.

Received in: 20/06/2016

Accepted for publication: 29/09/2016

Conflict of interest: none.

Source of funding: none.

\section{Mailing address:}

Wagner Augusto Schiel

E-mail:wagnerschiel@gmail.com wagnerschiel@hotmail.com 